\title{
Virulence of fungal spores and silver nano- particles from entomopathogenic fungi on the red palm weevil, Rhynchophorus ferrugineus Olivier (Coleoptera: Curculionidae)
}

\author{
M. A. Abdel-Raheem ${ }^{1 *}$, Huda A. ALghamdi ${ }^{2}$ and Naglaa F. Reyad ${ }^{2,3}$
}

\begin{abstract}
The red palm weevil, Rhynchophorus ferrugineus Olivier (Coleoptera: Curculionidae), is one of the most severe pests of date palms. The study aimed to evaluate the virulence of fungal spores and silver Nano-particles from entomopathogenic fungi (EPF) on R. ferrugineus under laboratory conditions. Concentrations of the fungal spores and the silver Nano-particles were prepared from Metarhizium anisopliae, Beauveria bassiana, and Verticillium lecanii. The results showed that the 3 EPF achieved $70-90 \%$ mortality rates within 7 days in egg stage. M. anisopliae and B. bassiana were the most effective ones. The isolate $V$. lecanii was tested on eggs, larvae, and adults. Spores of $M$. anisopliae increased eggs' mortality and reduced their hatchability. The egg mortality rate was $80 \%$ higher than the control. Seventy-percent adult mortality rate was achieved in 7 days, when treated with M. anisopliae, 60\% with B. bassiana, and 53\% with V. lecanii. M. anisopliae was more effective on R. ferrugineus than B. bassiana.
\end{abstract}

Keywords: Rhynchophorus ferrugineus, Entomopathogenic fungi, Virulence, Fungal spores, Silver nano-particles

\section{Background}

The red palm weevil, Rhynchophorus ferrugineus Olivier (Coleoptera: Curculionidae), is one of the severe pests of date palms (Giblin-Davis, 2001). It develops within the stipe of the date palm and subsequently destroys the vascular system causing collapse tree death of the plant. $R$. ferrugineus spreads in Europe Oceania, Africa, and Asia. In Southeast Asia, it has caused serious damage to coconuts, Giblin-Davis, (2001). In 1980s, it appeared in the Middle East, (Murphy and Briscoe, 1999). The first infestation in Jordan was reported in 1999 (Khan and Gangapersad, 2001). The adults of $R$. ferrugineus are attracted to the damaged and dying parts of palm trees, (Ferry and Gomez, 2002). Entomopathogenic fungi (EPF) have been studied as biological control agents (Shamseldean, 2004, Salama et al., 2004, Abdel-Raheem,

\footnotetext{
*Correspondence: abdelraheem_nrc@hotmail.com;

abdelraheem_nrc@yahoo.com

'Pests \& Plant Protection, Department, Agricultural and Biological Research Division, National Research Centre, 33rd ElBohouth St. - Dokki, Giza, Egypt Full list of author information is available at the end of the article
}

et al., 2009 \& 2016 and Abdel-Raheem, 2018). About 95 isolates of various microorganisms were isolated from Rhynchophorus spp.; only 3 isolates were EPF (Salama et al. 2004). Metarhizium anisopliae and Beauveria bassiana were isolated from R. bilineatus in Iran (Ghazavi and Avand-Faghih 2002). Beauveria sp. was found associated with cocoons of $R$. ferrugineus, (Shaiju-Simon et al. 2003). The EPF are infecting the host by contact and penetrating through the insect cuticle. The host can be infected by direct treatment, transmission of inoculum from treated insects, cadavers to untreated insects, or by a new generation of spores. Larvae and adults were contaminated by B. bassiana and M. anisopliae, reaching $50-100 \%$ mortality.

Fungi, bacteria, algae, and plant extracts are known to synthesize silver nano-particles (Ag NPs) (Nisha et al. 2017). Fungi such as Verticillium species are known to produce Ag NPs (Zonorodiam et al., 2016).

The aim of this study was to evaluate bio efficacy of nano-particles of EPF, $M$. anisopliae, B. bassiana, Bio Magic, Bio Power, and Bio Catch as fungal spores and 
silver Nano-particles on different life stages of R. ferrugineus (eggs, larvae, and adults) under laboratory conditions.

\section{Materials and methods}

Entomopathogenic fungi (Egyptian isolates)

Metarhizium anisopliae isolated from larvae and adults of the beet moth, Scrobipalpa ocellatella (Boyd) and Beauveria bassiana (Balsamo) Vuillemin, and isolated from the beet beetle, Cassida vittata (Vill) (Abdel-Raheem 2005), were grown on peptone media ( $10 \mathrm{~g}$ peptone, $40 \mathrm{~g}$ dextrose, $2 \mathrm{~g}$ yeast extract, $15 \mathrm{~g}$ Agar, and $500 \mathrm{ml}$ chloramphenicol). The media was autoclaved at $120^{\circ} \mathrm{C}$ for $20 \mathrm{~min}$ and poured into Petri-dishes $(10-\mathrm{cm}$ diameter $\times 1.5 \mathrm{~cm})$. Then, the incubated fungi were kept at $24 \pm 2{ }^{\circ} \mathrm{C}$ and $65 \pm 5 \% \mathrm{RH}$. The fungal isolates were re-cultured every 14-30 days and kept at $4{ }^{\circ} \mathrm{C}$.

\section{Commercial Indian compounds}

Three compounds (Indian productions), Bio Magic (M. anisopliae), Bio Power (B. bassiana), and Bio Catch ( $V$. lecanii), were obtained from the company of Seif Gaarah, Cairo, Egypt. The concentration of EPF used was $\left(1 \times 10^{9}\right.$ spores $\left./ \mathrm{ml}\right)$. Spores were harvested by rising with sterilized water and by adding $0.5 \%$ Tween 80 from culture peptone media 14 days old. The suspensions were filtered through cheese cloth to reduce mycelium clumping. The spores were counted in the suspension, using a hemocytometer $\left(0.1 \mathrm{~mm} \times 0.0025 \mathrm{~mm}^{2}\right)$. The concentrations were $(1 \times$ $10^{9}$ spores $/ \mathrm{ml}$ ) from each EPF. The grown fungal cultures were centrifuged at $12,000 \mathrm{rpm}$ fungal for 30 $\min$ at $25^{\circ} \mathrm{C}$ and the supernatant was used for the synthesis of Ag NPs.

\section{Insect rearing}

R. ferrugineus was reared in the Pests \& Plant Protection Department, National Research Centre, Giza, Egypt, on sugarcane as food and site (Rahalkar et al. 1985). Five pairs of adults were placed on a substrate of sugarcane sawdust or on sugarcane logs to mate and oviposit. $R$. ferrugineus was reared individually from the first larval instar to emergence of adults, at $27 \pm 2{ }^{\circ} \mathrm{C}$. The eggs were collected every other day.

\section{Bioassay}

M. anisopliae, B. bassiana, Bio Magic, M. anisopliae, Bio Power, B. bassiana, and Bio Catch, V. lecanii were tested by infecting the eggs, larval, and adults of $R$. ferrugineus. 100 Eggs, larvae and adults were used for each treatment, divided into 4 groups each of 25 eggs, larvae and adults placed in Petri-dishes, one individual/dish. The fungi were applied in a suspension in the control group, treated with sterilized water, and kept at $27 \pm 2{ }^{\circ} \mathrm{C}$ and $65 \pm 5 \%$ R.H. The mortality rates of $R$. ferrugineus were observed after 7 days.

\section{Biosynthesis of silver nano-particles}

Silver Nano-particles were synthesized by using $50 \mathrm{ml}$.

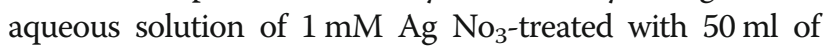
fungi culture (these particles prepared for all fungal isolates and commercial products) supernatant in a $250-\mathrm{ml}$ conical flask and the $\mathrm{PH}$ was adjusted to 8.5. The whole mixture was incubated at $40{ }^{\circ} \mathrm{C}$ at $200 \mathrm{rpm}$ for 7 days under a dark condition. The control was maintained without adding the culture supernatant to the solution of $\mathrm{Ag} \mathrm{No}_{3}$.

\section{Bioassay studies}

R. ferrugineus was placed in sterile Petri dishes having food and sterile filter paper. The nano-particle solution was sprinkled over the filter paper. The filter paper was allowed to air dry aseptically and incubated at $27 \pm 2{ }^{\circ} \mathrm{C}$ for 3 days. The experiment was replicated thrice. Mortality rate was recorded after 2 days from the treatment and $\%$ mortality was calculated.

\section{Data analysis}

Mortality data were recorded and percents of mortality in eggs, larvae, and adults were calculated. Corrected percent mortality was by use of Abbot's formula. Student's $t$ test or one-way ANOVA was used to compare the effects of the experimental and control treatments. Statistical analyses were performed by the Stat View for Power PC software, version 4.5 (Abacus Concepts, Inc., Berkeley, CA, USA).

\section{Results and discussion}

Data of the treated eggs of $R$. ferrugineus with $M$. anisopliae, B. bassiana, Bio Magic, Bio Power, and Bio Catch as fungal spores and their Silver NPs particles was presented in Table 1 . Seven days post treatment, up to $90 \%$ mortality rate of $R$. ferrugineus was recorded in the treated eggs. The $\%$ mortality rates attained $80,73,65,60$, and $45 \%$ by infection with fungal spores from $M$. anisopliae, B. bassiana, Bio Magic, Bio Power, and Bio Catch, respectively. Furthermore, the $\%$ mortality rates were $90,84,73,70$, and $58 \%$ by infection with biosynthesized Ag NPs from M. anisopliae, B. bassiana, Bio Magic, Bio Power, and Bio Catch, respectively during the same time. M. anisopliae recorded the highest mortality (90\%) in the eggs of R. ferrugineus, when treated with nano-particles or with fungal spores after 6 days and was the lowest (58\%) when treated with Bio Catch. According to Abdel-Raheem (2019a, 2019b) and Abdel-Rahman and Abdel-Raheem et al. (2018) the total mortality of eggs and larvae were reduced than 
Table 1 Mortality percent of entomopathogenic fungi on the eggs of Rhynchophorus ferrugineus, using spore suspension and biosynthesized silver nano-particles

\begin{tabular}{lll}
\hline Entomopathogenic & \multicolumn{2}{l}{ Treated with } \\
\cline { 2 - 3 } fungus & Fungal spores (mean \pm S.E) & Biosynthesized Ag NPs (mean \pm S.E) \\
\hline Metarhizium anisopliae & $80.0 \pm 1.20$ & $90.0 \pm 2.10$ \\
Beauveria bassiana & $73.0 \pm 1.00$ & $84.0 \pm 1.30$ \\
Bio Magic & $65.0 \pm 0.20$ & $73.0 \pm 0.10$ \\
Bio Power & $60.0 \pm 3.10$ & $70.0 \pm 0.20$ \\
Bio Catch & $45.0 \pm 0.20$ & $58.0 \pm 1.20$ \\
Control & 6.0 & 7.0 \\
S.E $(\mathrm{m})$ & 1.14 & 1.98 \\
\hline
\end{tabular}

the control group when eggs were exposed to M. anisopliae spores.

Abdel-Raheem (2019a, 2019b) mentioned that the reason of different pathogenicity rates between one fungus and another may due to the fraction exhibiting antimicrobial activity of some polar compounds ranging between 1000 and $1500 \mathrm{Da}$ in the extraction of fungi.

Data of larval mortality of $R$. ferrugineus, treated with $M$. anisopliae, B. bassiana, Bio Magic, Bio Power, and Bio Catch as fungal Spores and Silver Nano-particles was presented in Table 2. Seven days post treatment, $90 \%$ mortality of $R$. ferrugineus larvae was recorded as $84,75,71,65$, and $55 \%$ by infection with fungal spores from $M$. anisopliae, B. bassiana, Bio Magic, Bio Power, and Bio Catch, respectively. By infection with biosynthesized Ag NPs from $M$. anisopliae, B. bassiana, Bio Magic, Bio Power and Bio Catch, the mortality rates recorded were 95, 87, 77, 73 , and $60 \%$, respectively. M. anisopliae was the highest \% mortality (95\%) in the larvae of $R$. ferrugineus, when treated with the nano-particles or with the fungal spores after 6 days, while the lowest $(60 \%)$ was when treated with Bio Catch, V. lecanii. The results agree with Tefera and Pringle (2003) who reported that the bio efficacy of $M$. anisopliae in all stages of
R. ferrugineus caused up to 48 to $95 \%$ mortality of adult and larvae.

Data of adult mortality of $R$. ferrugineus, treated with $M$. anisopliae, B. bassiana, Bio Magic, Bio Power, and Bio Catch as fungal spores and silver nano-particles was presented in Table 3. Seven days post treatment, the percentage of mortality of $R$. ferrugineus adults reached $77 \%$. The $\%$ mortality rates recorded $65,61,56,52$, and $35 \%$ by infection with fungal spores from $M$. anisopliae, B. bassiana, Bio Magic, Bio Power, and Bio Catch, respectively, while by infection with biosynthesized Ag NPs from $M$. anisopliae, B. bassiana, Bio Magic, Bio Power, and Bio Catch, the $\%$ mortality recorded were $77,70,63,55$, and $48 \%$, respectively. $M$. anisopliae was the highest \% mortality (77\%) in the adults of $R$. ferrugineus, when treated with the Nano-particles or with fungal spores after 6 days, while the lowest was (48\%), when they were treated by Bio Catch. Gothandapani et al. (2015) stated that the EPF are eco-friendly and have the bio control potential against insect pests. Biology synthesis of silver nano-particles (Ag NPs) had given a new scope for a non-toxic environment (Subha et al. 2017 and Deeba et al. 2017). El Husseini (2019) treated the adults and larvae of $R$. ferrugineus with conidiospores of EPF B. bassiana and reported that the mortality reached to $100 \%$.

Table 2 Mortality percent of entomopathogenic fungi on the larvae of Rhynchophorus ferrugineus using spore suspension and biosynthesized silver nano-particles

\begin{tabular}{lll}
\hline Entomopathogenic & Treated with & Biosynthesized Ag NPs (mean \pm S.E) \\
\cline { 2 - 3 } fungus & Fungal spores (mean \pm S.E) & $95.0 \pm 2.30$ \\
\hline Metarhizium anisopliae & $84.0 \pm 2.10$ & $87.0 \pm 2.22$ \\
Beauveria bassiana & $75.0 \pm 2.12$ & $77.0 \pm 1.10$ \\
Bio Magic & $71.0 \pm 2.20$ & $73.0 \pm 1.20$ \\
Bio Power & $65.0 \pm 1.10$ & $60.0 \pm 1.00$ \\
Bio Catch & $55.0 \pm 0.10$ & 7.3 \\
Control & 6.2 & 3.00 \\
S.E $(\mathrm{m})$ & 2.10 & \\
\hline
\end{tabular}


Table 3 Mortality percent of entomopathogenic fungi on the adults of Rhynchophorus ferrugineus using spore suspension and biosynthesized silver nano-particles

\begin{tabular}{lll}
\hline Entomopathogenic & Treated with & Biosynthesized Ag NPs (mean \pm S.E) \\
\cline { 2 - 3 } fungus & Fungal spores (mean \pm S.E) & $77.0 \pm 1.30$ \\
\hline Metarhizium anisopliae & $65.0 \pm 2.00$ & $70.0 \pm 2.10$ \\
Beauveria bassiana & $61.0 \pm 1.20$ & $63.0 \pm 0.10$ \\
Bio Magic & $56.0 \pm 2.20$ & $55.0 \pm 3.20$ \\
Bio Power & $52.0 \pm 1.20$ & $48.0 \pm 0.20$ \\
Bio Catch & $35.0 \pm 0.00$ & 8.0 \\
Control & 7.0 & 2.90 \\
S.E $(\mathrm{m})$ & 1.94 &
\end{tabular}

\section{Conclusion}

The results proved that use of the Ag NPs synthesized through application of spore suspension and biosynthesized silver nano-particles showed an efficacy against $R$. ferrugineus at different stages. $M$. anisopliae had the highest potential and was more effective than all the others.

\section{Acknowledgements}

The authors extend their appreciation to the Deanship of Scientific Research at King Khalid University, Abha, KSA for funding this study through Research Groups Program under grant number (R.G.P.1/78/40).

\section{Authors' contributions}

The authors declare that this work was done by the authors named in this article and all liabilities pertaining to claims relating to the content of this article will be borne by them. All authors read and approved the final manuscript.

\section{Funding}

The study was supported by King Khalid University, Abha, KSA for funding this study through Research Groups Program under grant number R.G.P.1/ $78 / 40$.

\section{Ethics approval and consent to participate}

Not applicable

\section{Consent for publication}

Not applicable

\section{Competing interests}

The authors declare that they have no competing interest.

\section{Author details}

${ }^{1}$ Pests \& Plant Protection, Department, Agricultural and Biological Research Division, National Research Centre, 33rd ElBohouth St. - Dokki, Giza, Egypt. ${ }^{2}$ Biology Department, College of Science, King Khalid University, Abha, Saudi Arabia. ${ }^{3}$ Plant Protection Research Institute A. R. C. Dokki, Giza, Egypt.

Received: 17 October 2019 Accepted: 19 December 2019

Published online: 30 December 2019

\section{References}

Abdel-Raheem M, Al-Shuraym L, Al-keridis L (2016) Date palm pests and their control, Lambert Academic Publishing, Pp. 76. https://www.morebooks.de/ store/gb/book/date-palm-pests-and-their-control/isbn/978-3-659-97440-3. Published in 19-10-2016

Abdel-Raheem MA (2005) Possibility of using the Entomopathogenic Fungi Beauveria bassiana and Metarhizium anisopliae for controlling the sugar-beet insects Cassida vittata Vill. and Scrobipalpa ocellatella Boh. In Egypt, Ph.D. Faculty of Agriculture, Cairo University, Cairo., P 86
Abdel-Raheem MA (2019a) Pathogenicity comparative of some Egyptian isolates and commercial Indians compounds of Entomopathogenic fungi against some insect pests. Plant Arch 19(1):1061-1068

Abdel-Raheem MA (2019b) Entomopathogenic fungus, Beauveria bassiana, Lambert Academic Publishing P148. https://www.morebooks.shop/gb/ search?utf8=\%E2\%9C\%93\&q=978-613-9-44933-0. Published in 4-2-2019

Abdel-Raheem MA, KH, Sabry KH, Zakia AR (2009) Effect of different fertilization rates on control of Bemisia tabaci (Genn.) by Virticillium lecanii and Beauveria bassiana in potato crop. J Biol Pest Control 19(2):129-133

Abdel-Raheem M A, Reyad N, Abd El-Rahman E (2018) Entomopathogenic fungi, effective, safe and cheap applications, Lambert Academic Publishing, p. 80. https://www.morebooks.de/store/us/book/entomopathogenic-fungi,-effective,safe-and-cheap-applications/isbn/978-613-9-85211-6. Published in 5-6-2018

Abdel-Rahman IE, Abdel-Raheem MA (2018) Using entomopathogenic fungi as bio agents control on the red palm weevil, Rhynchophorus ferrugineus (Olivier) (Coleoptera: Curculionidae). J Entomol Zool Stud 6(6):387-390 http:// www.entomoljournal.com/archives/2018/vol6issue6/PartG/6-5-342-932.pdf

Deeba K, Prameeladevi T, Sankar G, Nr NR, Shan PT (2017) Green synthesis of silver nano particles by entomopathogenic fungus Beauveria bassiana and their bio efficacy against mustard aphid (Lipaphis erysimi kal.). Indian J Exp Biol 55:555-561

El Husseini M (2019) Efficacy of the fungus Beauveria bassiana (Balsamo) Vuillemin on the red palm weevil Rhynchophorus ferrugineus Olivier (Coleoptera: Curculionidae) larvae and adults under laboratory conditions. Egyptian J Biol Pest Control 29:58. https://doi.org/10.1186/s41938-019-0155-3

Ferry M, Gomez S (2002) The red palm weevil in the Mediterranean area. Palms 2002:46 http://www.palms.org/palmsjournal/2002/redweevil.htm

Ghazavi M, Avand-Faghih A (2002) Isolation of two entomopathogenic fungi on red palm weevil, Rhynchophorus ferrugineus (Olivier) (Col., Curculionidae) in Iran. Appl Entomol Phytopathol 9:44-45

Giblin-Davis RM (2001) Borers of palms. in: Howard, F.W., Moore, D., Giblin-Davis, R.M. and Abad,bR.G. [Eds.] Insects on Palms. CABI Publishing, Walling ford 267-305

Gothandapani S, Boopalakrishanan G, Prabhakaran N, Chethana BS, Aravindhan M, Saravanakumar M, Ganeshan G (2015) Evaluation of entomopathogenic fungus against Alternaria porri (Ellis) Causing purple blotch disease of onion. Arch phytopathol pfl 48:135

Khan A, Gangapersad G (2001) Comparison of the effectiveness of threeentomopathogenic fungi in the management of the banana borer weevil, Cosmopolites sordidus (Germar) (Coleoptera: Curculionidae). Int Pest Control 43:208-213

Murphy ST, Briscoe BR (1999) The red palm weevil as an alien invasive: biology and prospects for biological control as a component of IPM. Biocontrol News Inf 1999(20):35-45

Nisha C, Bhawona P, Fulekar MH (2017) Antimicrobial potential of green synthesized silver nanoparticles using sida acuta leaf extract, Vano Sci. Nano Technol 11:111

Rahalkar GW, Harwalkar MR, Rananavare HO, Tamhankar AJ, Shanthram K (1985) Rhynchophorus ferrugineus. In: Singh P, Moore RF (eds) Handbook of insect rearing, vol 1, pp 279-286

Salama HS, Foda MS, El-Bendary MA, Abdel-Razek A (2004) Infection of red palm weevil, Rhynchophorus ferrugineus, by spore-forming bacilli indigenous to its natural habitat in Egypt. J Pestic Sci 77:27-31 
Shaiju-Simon, Kumar RK, Gokulapalan C (2003) Occurrence of Beauveria sp. on red palm weevil, Rhynchophorus ferrugineus (Oliv.) of coconut. Insect Environ 9: 66-67

Shamseldean MM (2004) Laboratory trials and field applications of Egyptian and foreign entomopathogenic nematodes used against the red palm weevil, Rhynchophorus ferrugineus. Oliv Int J Nematol 2004(14):44-55

Subha PK, Esther RM, Gunaseeli R, Hussain MM (2017) Extracllular synthesis of silver nanoparticles by the fungus Emericella nidulans EV4 and its application. Indian J Exp Biol 55:262

Tefera T, Pringle KL (2003) Food consumption by Chilo partellus (Lepidoptera: Pyralidae) larvae infected with Beauveria bassiana and Metarhizium anisopliae and effects of feeding natural versus arti_cial diets on mortality and mycosis. J Invertebr Pathol 84:220-225

Zonorodiam K, Pourshahid S, Sadatsharifi A (2016) Bio synthesis and characterization of silver nanoparticles by Aspergillus species. Bio Med Res Int 2016:6 Article ID 5435397. http://dx.doi.org/10.1155/2016/5435397

\section{Publisher's Note}

Springer Nature remains neutral with regard to jurisdictional claims in published maps and institutional affiliations.

\section{Submit your manuscript to a SpringerOpen ${ }^{\circ}$ journal and benefit from:}

- Convenient online submission

- Rigorous peer review

- Open access: articles freely available online

- High visibility within the field

- Retaining the copyright to your article

Submit your next manuscript at $\boldsymbol{\wedge}$ springeropen.com 